\title{
IMPROVING THE STUDENTS' SPEAKING SKILLS THROUGH 5E LEARNING CYCLE MODEL AT THE TENTH GRADE STUDENTS OF SMA NEGERI 3 PINRANG
}

\author{
Hasnidar $^{1}$, Nurhamdah ${ }^{2}$, Ismail ${ }^{3}$ \\ English Education Program, Tarbiyah Faculty, State Islamic Institute of Parepare ${ }^{123}$
}

\begin{abstract}
This study was aimed to see the Improving Speaking Skill at SMA Negeri 3 Pinrang. The objective of this research is to get the empirical data of the differences between students' score of speaking test who were taught by using 5E learning cycle model and to know how 5E learning cycle model in teaching speaking. The research problem this study was "can 5e learning cycle model improve the speaking skills".

The research method used in this research was pre-experimental with one group design. The data was collected through pretest and posttest. It aimed to know whether $5 \mathrm{E}$ learning cycle model in teaching speaking can improve students' speaking skill. The population of this research consist of 280 students and the sample of the research X IS 3 that consist of 35 students.

The finding revealed that 5E learning cycle model able to imropve students' speaking skills; it can be seen from the students score pre-test and post-test. the mean score of the pre-test score of the class was 1.48 and the mean score of the post-test score in class was 1.98 . It means that teaching-learning by using $5 \mathrm{E}$ learning cycle model can be improved students' speaking skills.
\end{abstract}

Keywords:Improving Speaking Skill, 5E Learning Cycle Model. 


\section{Introduction}

Organizing thought is the common work of human being and speaking can be truly considered as the primary one and the most importance of the two productive skills which let people to organize their thoughts. The one of example when individuals try to organize or express their thought most likely occurs if they find some topic to talk with when it is used to stimulate their thought. Indeed, when they would like to express their thought probably argument based thought, they must speak in order to express. As the one of two productive skills, it is also looked when they also do in the process of writing. Every individual is taught how to speak since in very young age.

A 51-years-old Finish learner of English says that speaking English is a difficult task: he understands the language and knows a lot about grammar and lexion, but when he has to speak, he seems to be loss for words. This is a problem that other people have noticed as well. For example, Tatham and Morton state that many people report that they can understand a language but they cannot speak it. There are also other countries where people experiences the same phenomenon. For example in the Japanese context it seems that many people have difficulties in speaking English.

Knowing the certain issues regarding to the importance of speaking above, there are some models that can be simply used by the teacher to stimulate students' interest to improve students' speaking skill. One of the suitable models is the " $5 \mathrm{E}$ Learning Cycle Model”.

The 5E learning cycle model consists of five stages that are related to each other. "5E Learning Cycle has several phases which consist of engagement, 
exploration, explanation, elaboration, and evaluation". "Each phase in the 5E learning cycle model contributes learners to better understand scientific knowledge". Each phase has a specific function and contributes to the coherent instruction of the teacher as well as to the students' formulation of a better understanding of scientific and technological knowledge, attitudes and skills. This model also helps to develop students' critical skills to help them adapted better to the demands of adaptability, complex communication or social skills.

Throughout history, there have been many attempts to find out the best way of teaching English and creating the most effective design. Although methods, approaches, tecniques, materials, roles of the teacher and students have changed; a perfect model has never been created. In this research, the 5E Model, a new model of one of the well-known approaches, Contructivism, is going to be introduced in a new area. Even though the origins of this model come from Biological Science which seems to be quite unrelated to English Language Teaching (ELT), the 5E Model is cosidered to contribute greatly in foreign language teaching as well. It is thought to be effective in providing a sequence of instruction that places students at the center of their prior experiences. Thus, the aim is to encourage students to explore and construct their own understandings of the new subjects.

Speaking is one of the four languages skills that are taught in the teaching of English. Speaking essentially is very important in learning a language because as a social creature human need to interact one and another to express ideas and thoughts to arrange and persuade others and it is used because someone purposes in learning a language is to be able to communicate the language. "Speaking is the active use of language to express meaning so that other people can understand it". Furthermore, in 
speaking there is a process of transferring information between the speakers and listeners.

People use speaking ability to communicate with other people through expressing ideas, sharing opinions, revealing fellings, exchanging arguments and discussing something. "Speaking is the terms of capability which is express the main what we want to extend". In additional, "Speaking is the verbal use of language to communicate with other".

From the discussion above, the researcher assumes that speaking is one of tools or elements of communication. As a human being, all of them always need communication to express our idea to do everything, Unlike writing and reading, speaking also involves nonverbal codes to keep the listener's attention and understanding of the speaker's meaning what's more as a students or learners they have to speak with their teacher as long as in learning process to express their idea.

The 5E Learning Cycle Model was a learning model based on learners (student centered) because students prosecuted plays and active role to explore and enrich their understanding of against the concept learned. The learning cycle model was a series of phase of activities organized in such a way so that students can master the competencies to be achieved in learning with the road acting active. The $5 \mathrm{E}$ Learning Cycle Model was developed by one of the leading names of the BSCS (Biological Science Curriculum Study) project, Rodger Bybee. The BSCS 5E Learning Cycle Model is the most effective way of engaging students in learning. Developed in the 1980s, the BSCS 5E Learning Cycle model is a hallmark of these programs.

The 5E learning cycle model is a constructivist model which provides learning a new concept or comprehension deeply a known concept. This model which increases students' research, by satisfying expectations of students, consist of active research's skill and activities that are necessary for knowledge and comprehension. The 5E model targets at the discovery and association with previous knowledge of 
new concepts by students. With the aid of planned and applied learning-teaching activities, students from themselves their own knowledge about a specific problem. $5 \mathrm{E}$ model motivates students to be included into a topic by several phases of learning, to explore a subject, to be given a definition for their experiences, to obtain more detailed information about their learning and to evaluate it. 5E learning cycle model is one of the complete constructivist models in the cases of research-based learning or brainstorming which are used in the classroom. Students have to think creatively and complex for overcoming problems and difficulties and as result, they have to think in an integrative manner in order to unify their thoughts. This situation can only occur when students have higher order thinking skills. These skills are called also critical thinking skills. Grounded on the constructivist, 5E learning and teaching model includes higher order thinking skills. Stimulating students to explore, to inquiry, to get experiences, $5 \mathrm{E}$ model transmits also the critical thinking skill to students. $5 \mathrm{E}$ model is learning cycle model that facilitates learning and creates beneficial opportunities for students while learning.

Tajari stated that there are five stages of structuralism teaching $5 \mathrm{E}$ Learning Cycle Model were as following:

1. Engagement in the subject: (Engagement): In a way, student was engaged in the subject, was attracted and was interested, for example by showing a picture or telling a story, making a question or performing a play, etc.

2. Investigation and exploration (Exploration): In this stage children search by observation, measurement, and experiment about subject. Student dares to ask questions and teacher was just as a guide.

3. Description and explanation of subject (Explanation ): We want them to tell their findings, it is not important whether they are true or not, but he or she should have ability of defending his or her findings by reasoning and here 
teacher corrects the childrens ideas and tells them scientific concepts and expressions of the lesson.

4. Improvement and elaboration of subject (Elaboration): Complete explanation was presented by students and in this way we make them to think and we explain the subject more by making questions about it and want them to reffere to other books for better understanding of the subject.

5. Evaluation: (Evaluation): Evaluation of the lesson is done in order to see whether students have achieved to determined purposes or not it is usually done in group and actively.

\section{Research Method}

This research is pre-experimental with one-group pretest-posttest design. It involves one class. That is experimental class wich is implemented $5 \mathrm{E}$ learning cycle model in teaching-learning process for improving students' speaking skills at SMA Negeri 3 Pinrang.

The location of the research took a place at SMA Negeri 3 Pinrang. The research used the quantitative research that has several times to collect and analyze data. The researcher did the research almost two months for collecting data from pretest, treatment and post-test.

The population of the research was all students of the tenth year students of SMAN 3 Pinrang which consist of eight classes. To make it clear the population of the research, it can be seen in the table below:

In this research, the research took the sample from the tenth grade students of SMAN 3 Pinrang which consist of eight classes. The research used purposive sampling to take the sample that is in accordance with the criterias needed in this 
research. The researcher chose X IPS 3 as experimental class because the researcher has two reasons: firstly, based on the observation and interview from the English teacher of SMAN 3 Pinrang, X IPS 3 has low skill of speaking and secondly, it'll be better to choose the class which has a low skill to know the significant improvement of studens' speaking skill by comparing the students' score result, so the researcher took X IPS 3 to be sample which consist of 35 students.

The instrument of this research used speaking test in the form interview test. The researcher used interview test as instrument for pre-test and post-test. The procedure of the interview test, the researcher interviewed the students about their personality.

\section{Finding And Disscussion}

The result of the pre-test and post-test showing in the following table.

Table 1. The mean score and standard deviation of the pre-test and post-test

\begin{tabular}{lll}
\hline Test & Mean Score & Standard Deviation (SD) \\
\hline Pre-test & 51.8 & 0.290 \\
Post-test & 69.4 & 0.272 \\
\hline
\end{tabular}

The data in table 4.5 shows that the mean score of the pre-test was 51/8 $\left(\mathrm{X}_{1}\right)$ while the mean score of the post-test increased 69,4 $\left(\mathrm{X}_{2}\right)$. The standard deviation of pre-test was 0,290 (SD) while the standard deviation of the post-test was 0,272 (SD).

The following table shows the percentage of the frequency in pre-test and post-test. 
Table 2. The rate percentage of the frequency of the pre-test and post-test

\begin{tabular}{lllllll}
\hline \multirow{2}{*}{ No. } & \multirow{2}{*}{ Classification } & \multirow{2}{*}{ Score } & \multicolumn{2}{c}{ Frequency } & \multicolumn{2}{c}{ Percentage } \\
\cline { 3 - 7 } & & & Pre-test & Post-test & Pre-test & Post-test \\
\hline 1. & Excellent & $3.51-4.00$ & 0 & 0 & $0 \%$ & $0 \%$ \\
\hline 2. & Good & $2.51-3.50$ & 0 & 2 & $0 \%$ & $5,7 \%$ \\
\hline 3. & Enough & $1.51-2.50$ & 13 & 33 & $37.1 \%$ & $94,3 \%$ \\
\hline 4. & Poor & $1.00-1.50$ & 22 & 0 & $62.9 \%$ & $0 \%$ \\
\hline & Total & & 35 & 35 & $100 \%$ & $100 \%$ \\
\hline
\end{tabular}

The data of the table above indicated that the rate percentage of the pre-test thirteen $(37.1 \%)$ students got enough score and twenty two (62.9\%) students got poor score while the rate percentage of the post-test, two $(5,7 \%)$ students got good score and thirty three $(94,3 \%)$ students got enough. The percentage in post-test that students got good score was higher than percentage in pre-test. It shows that students were able to improve their speaking skills after did the treatment that using 5E learning cycle model.

For the level, significant (p) $5 \%$ and $\mathrm{df}=34$, and the value of the table is 1.690 , while the value of t-test is 2.411 .

Table 3. The test of significance

\begin{tabular}{lll}
\hline Variable & T-test & T-table value \\
\hline Pre-test - post-test & 2.411 & 1,690 \\
\hline
\end{tabular}

The data above showed that $\mathrm{t}$-test is higher than $\mathrm{t}$-table $(2.411 \geq 1.690)$. thus, it can be concluded that the students' speaking skills through 5E learning cycle model in significant $5 \%$ is better after getting the treatment. So, the null hypothesis $\left(\mathrm{H}_{0}\right)$ is rejected and the alternative hypothesis $\left(\mathrm{H}_{\mathrm{a}}\right)$ is accepted. 
Formed on the research statement in the previous chapter, the 5E learning cycle model can make students more active. Firstly, it can make students more active in group disscussions and make students more confident to convey their ideas. It is accordance with what Rodger Bybee said the learning cycle model was a series of phase of activities organized in such a way so that students can master the competencies to be achieved in learning with the road acting active. Secondly, it can make students understanding with the topic. It is accordance with what $\mathrm{O}$. Anil and V. Batdi said the 5E learning cycle model leading students to focus on active in learning and make students understanding. Thirdly, it can make students get a new learning experience in the classroom. It is accordance with what Abdulkadir Tuna and Ahmet Kacar said the 5E model targets at the discovery and association with previous knowledge of new concepts by students. With the aid of planned and applied learning-teaching activities, students form themselves their own knowledge about a specific problem. $5 \mathrm{E}$ model motivates students to be included into a topic by several phases of learning, to explore a subject, to be given a definition for their experiences, to obtain more detailed information about their learning and to evaluate it.

Based on the data, it is found that the mean score of the pretest score of the class is 1.48 the mean score of the postest score of the class is 1.98 . It can be seen that the students' learning by using 5E learning cycle model can be implemented in teaching speaking skills.

\section{Conclusion}

Based on the result the observation and discussion, it can be concluded that $5 \mathrm{E}$ learning cycle model is more effective to improve the students' speaking skills compared to the conventional teaching. The data show that there is a significant different in the mean score between the students who are taught English speaking by 
using 5E learning cycle model. Therefore, from the difference of the pre-test and post-test show that the students' score increase significantly after they are teach using 5E learning cycle model.

From the table of the scores showed that t-test is higher than t-table $(2.411 \geq$ 1.690). thus, it can be concluded that the students' speaking skill through 5E learning cycle model in significant $5 \%$ is better after getting the treatment. So, the null hypothesis $\left(\mathrm{H}_{0}\right)$ is rejected and the alternative hypothesis $\left(\mathrm{H}_{\mathrm{a}}\right)$ is accepted.

After observation and analysing the data, the researcher would like to give the suggestion for teachers and further researcher. It is expected that is gives benefits for the teaching learning method in the future especially in teaching speaking:

Teachers can use 5E learning cycle model as the alternative variation in teaching speaking for tenth grade. 5E learning cycle model is recommended to students shouldn't be afraid in making mistakes when they are learning English, and make the students active in class. The researcher suggests to the other researchers not only focus on speaking skill but they can implement 5E learning cycle model in other skills such as Reading. Furthermore, the result can be used as the reference for further research in another topic discussion, in different English language skills by the deeper investigation.

\section{References}

Amold, Edward. 1991. Second Language Learning and Teaching. New York: British Library.

Ananda, Rusydi and Fadhli, Muhammad. 2018. Statistik Pendidikan: Teori dan Praktik dalam Pendidikan. Medan: CV Widya Puspita.

Anil, O and Batdi, V. 2015. A Comparative Meta-Analysis of 5E and Trational Approaches in Turkey. Journal of Education and Training Studies. 
Arikunto Suharsimi. 2009. Dasar-dasar Evaluasi Pendidikan. Jakarta: Bumi Aksara

Bahar, A. Kaharuddin. 2013. The Communicative Competence-Based English Language Teaching. Yogyakarta: Trusmedia.

2014. Interactional Speaking a Guide to Enhance Natural Communicational Skill in English. Yogyakarta: Trust Media Publishing.

Barry and Burke. 2014. 6E Learning by Design Model, Technology and Engineering Teacher.

Brown, H. D. 2001. Teaching by Principles. $2^{\text {nd }}$ Ed.; New York: Longman.

Brown, H. D. 2004. Language Assesment Priniples and Classroom Preatice. San Fancisco State University.

Cahyarini, A. 2016. The Effect of 5E Learning Cycle Instrutional Model Using Socientific Issues (SSI) Learning Context on Students' critical thinking. Jurnal Pendidikan IPA Indonesia.

Cameron, L. 2011. Teahing Languages to Young Learners. Cambridge: Cambridge University Press.

Cosgun Ogeyik, Muhlise. 2011. The Effect of The 5E Model in Writing on Achievement and Motivation. Published Thesis: Trakya University.

Ergin. 2012. Constructivist Approach Based 5E Model and Usability Instructional Physics. Lat. Am. J. Phys. Educ.

Fulcher. G. 2003. Testing Second Language Teaching. Harlow: Longman/Pearson Education.

Harmer, Jeremy. 2007. How to Teach English. Harlow: Pearson Education Limited.

Harris, L. T. and Hodges. R. E. 1995. The Literacy Dictionary: The Vocabulary of Reading and Writing. New York: Internatinal Reading Association.

Henna, Paaki. 2013. Difficulties in Speaking English and Perceptions of Accents a Comparative Study of Finnish Japanese Adult Learners of English. Kuopio: Uniersity of Eastern Findland.

Kayi Hayriye. "Teaching Speaking: Activities to Promote Speaking in a Second Language." 2019. The Internet TESL Journal. http//:iteslj.org/Technique/Kayi-TeachingSpeaking.html (28 Juni). 
Kanan, R. Difficulties in Speaking English as Foreign Language.

Kulsum, U. and Hindarto, N. 2011. Penerapan Learning Cycle Model pada Sub Pokok Bahasan Kalor untuk Meningkatkan Keaktifan dan Hasil Belajar Siswa Kelas VII SMP. Jurnal Pendidikan Fisika Indonesia.

Nawastheen, F. M. Puteh. S. N, Meerah T. S. 2014. Teachers' Levels of Use of the $5 \mathrm{E}$ Intructional Model in the Implementation of Curriculm Reforms in Sri Lanka. Research Journal of Applied Sciences.

Purwanto, A. 2011. Implementasi Model Cycle 5E disertai LKS untuk Meningkatkan Aktifitas, Keterampilan Proses Sains dan Hasil Belajar Biologi. Pendidikan Biologi FKIP Universitas Muhammadiyah Metro.

Saepudin, et al., eds. 2013. Pedoman Penulisan Karya Ilmiah: Makalah dan Skripsi. Parepare: STAIN.

Sartika, Rody Putra. 2017. Implementation of 5E Learning Cycle Model on Process Science Skill Prospective Student Teacher of University of Tanjungpura. International Conference on Teaching and Education.

Siddiqui .2016. Effectiveness of 5E Learning Cycle Model of Constructivist Approach on Ninth-Grade Students' Understanding of Suspensions. Global Journal For Research Analysis.

Suciati. 2015. Application of Learning Cycle Model (5E) Learning with Chart Variation Toward Student Creativity. Jurnal Pendidikan IPA Indonesia.

Sugiyono. 2017. Metode Penelitian Pendidikan: Pendekatan Kuantitatif, Kualitatif dan $R \& D$. Bandung: Alfabeta.

Tajariand, T. and Haghani, F. 2013. Effectiveness of Structuralism Teaching Method (5E) about Creativity. International Journal of Basic Sciences \& Applied Research.

Tuna Abdulkadir and Ahmet Kacar. 2013. The Effect of Learning Cycle Model in Teaching Trigonometry on Students' Academic Achievement and the Permanence of Their Knowledge. International Journal on New Trends in Education and Their Implications

Ur. Penny. 1996. A Course in Language Teaching. Cambridge: Cambridge University Press. 
Utari, et.al. 2013. Application of Learning Cycle 5E Model Aided Cmaptools-Based Media Prototype to Improve Student Cognitive Learning Outcomes, Applied Physics Research. 